\title{
BioéthiqueOnline
}

\section{The Anxious Heart of Injustice: Negative Affective Responses to Disabilities}

\section{Jonas-Sébastien Beaudry}

Volume 5, 2016

URI : https://id.erudit.org/iderudit/1044286ar

DOI : https://doi.org/10.7202/1044286ar

Aller au sommaire du numéro

Éditeur(s)

BioéthiqueOnline

ISSN

1923-2799 (numérique)

Découvrir la revue

Citer cet article

Beaudry, J.-S. (2016). The Anxious Heart of Injustice: Negative Affective

Responses to Disabilities. BioéthiqueOnline, 5. https://doi.org/10.7202/1044286ar
Résumé de l'article

Il semble que la pensée libérale accorde trop peu d'attention aux réactions affectives négatives envers les personnes handicapées. Par conséquent, les théories libérales peuvent manquer de structures correctives pour traiter efficacement ces émotions et les théoricien(ne)s eux-mêmes peuvent devenir la proie de leur influence. En supposant que ces suggestions inquiétantes soient tout au moins partiellement bien fondées et justifient un approfondissement, cet essai examine trois causes hypothétiques relatives à cette situation: la méfiance philosophique envers les émotions, l'échec à reconnaître les réactions d'anxiété que suscitent les anomalies corporelles et la crainte de la vulnérabilité liée à l'idéologie libérale. Bien que ces facteurs de causalité soient difficiles à évaluer, ils sont néanmoins intuitivement convaincants.
Droits d'auteur (C) J-S Beaudry, 2016

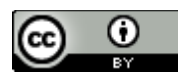

Ce document est protégé par la loi sur le droit d'auteur. L'utilisation des services d’Érudit (y compris la reproduction) est assujettie à sa politique d'utilisation que vous pouvez consulter en ligne.

https://apropos.erudit.org/fr/usagers/politique-dutilisation/ 


\title{
The Anxious Heart of Injustice: Negative Affective Responses to Disabilities
}

\author{
EsSAI / EsSAY \\ Jonas-Sébastien Beaudry ${ }^{1}$ \\ Reçu/Received: 17 Jan $2016 \quad$ Publié/Published: 16 Sept 2016 \\ Éditeurs/Editors: Maude Laliberté \& Stephen Clarke \\ Travail créatif/Creative work: M. Le Mée. Mael-e(s)t-France. BioéthiqueOnline 2016;5/27
}

2016 J-S Beaudry, Creative Commons Attribution 4.0 International License

\begin{abstract}
Résumé
Il semble que la pensée libérale accorde trop peu d'attention aux réactions affectives négatives envers les personnes handicapées. Par conséquent, les théories libérales peuvent manquer de structures correctives pour traiter efficacement ces émotions et les théoricien(ne)s eux-mêmes peuvent devenir la proie de leur influence. En supposant que ces suggestions inquiétantes soient tout au moins partiellement bien fondées et justifient un approfondissement, cet essai examine trois causes hypothétiques relatives à cette situation: la méfiance philosophique envers les émotions, l'échec à reconnaître les réactions d'anxiété que suscitent les anomalies corporelles et la crainte de la vulnérabilité liée à l'idéologie libérale. Bien que ces facteurs de causalité soient difficiles à évaluer, ils sont néanmoins intuitivement convaincants.
\end{abstract}

Mots clés

émotions, réponse affective, libéralisme, handicap

\section{Summary}

It appears that liberal thought pays too little attention to negative affective responses toward people with disabilities. As a result, liberal theories may lack corrective structures to deal with such emotions and theorists themselves may fall prey to their influence. Assuming these troubling suggestions are at least partly well-founded and thereby warrant closer investigation, I examine three hypothetical causes of this state of affairs: the philosophical distrust toward emotions, the failure to attend to anxious reactions toward anomalous bodies, and the fear of vulnerability connected to liberal ideology. Although the causal factors that $I$ discus are difficult to demonstrate empirically, they are nonetheless intuitively compelling.

\section{Keywords}

emotions, affective responses, liberalism, disability

Affiliations des auteurs / Author Affiliations

${ }^{1}$ Allard School of Law, University of British Columbia, Vancouver, Canada

\section{Correspondance / Correspondence}

Jonas-Sébastien Beaudry, beaudry@allard.ubc.ca

\section{Remerciements}

J'aimerais remercier Dr Aruna Nair pour ses généreux et perspicaces commentaires sur le brouillon de cet essai.

\section{Conflit d'intérêts}

Aucun déclaré

\section{Acknowledgements}

I wish to thank Dr Aruna Nair for her generous and intelligent comments on a draft of this essay.

\section{Conflicts of Interest}

None declared

\section{The Project}

In late 2015, I had a series of discussions with the French artist Mael Le Mée in preparation for the exhibition Art + Bioéthique that was to be curated at the Gallery Espace Projet, on February 25, 2016, in Montreal. The goal of this interdisciplinary endeavour was to pair emerging artists with junior researchers in bioethics, in order for them to create a work of art and an academic text mutually inspired by their respective research and craft.

One of the topics closest to my heart is how moral, political and legal discourses conceptualize the "subject". The issue arises across a variety of fields: political bioethics, disability studies and the law, to name a few. Whoever gets to define who is a "person" - a subject of justice, a moral subject, a possessor of robust "moral status" or legal standing - gets to cast some potential persons out of the 
moral universe or out of the legal order. A historical list of such past and present castaways includes: brain-dead people, animals, fetuses, women, slaves and people with severe mental disabilities.

In my own work, I examine how diverse institutions (from individual families to the redistributive mechanisms of the state) attempt to "normalize" people with disabilities. While well-meaning and sometimes successful [1], normalizing strategies can also be harmful to disabled people and comfort rather than destabilize ableist assumptions underlying these institutional efforts [2].

Some of Mael's artistic creations made use of reproductions of organic materials and medical technologies, and he was highly interested in the theme of bodily mutations [3]. I was surprised how intrigued Mael was by what seemed like abnormal forms of embodiment. One of our discussions, for instance, mentioned the aesthetics of "freak shows", and the fascination or negative emotional reactions that people have vis-à-vis abnormal embodiments. Our exchanges had two results: first, I expressed concerns about an artistic project that would use people with disabilities to cause negative reactions in an audience. Second, it prompted me to explore theories that would make sense of such strong emotional reactions. This took me outside of my usual fields of research (analytic legal and moral theory) and into a fascinating new terrain (psychoanalysis and poststructuralist theory). My modest goal was to bring back from this continental journey one or two artefacts that might be usefully added to the toolkit of social justice theorists.

I note that some liberal thinkers, such as Martha Nussbaum, do think about emotions and write insightfully about it [cf. 4-8]. Similarly, it would be unfair to say that "relational" liberals, such as Elizabeth Anderson [9] or Iris Marion Young [10], ignore emotions: their arguments, on the contrary, pay great attention to oppressive and disrespectful social relations that are often coloured by affective prejudices. Nonetheless, discussions on the role of emotions remain peripheral to mainstream liberal thought, as expressed in university curricula, conferences and journals. It is at least clear that an important portion of canonical liberal writings pay little attention to these affective phenomena. To assert that this lacuna impoverishes these writings would beg the question. Instead, I want to examine the following apparent paradox. On the one hand, positive and negative affective states (by which I mean emotions like disgust, pity, empathy, caring, etc.) seem to greatly influence phenomena that liberal thinkers spend much time struggling against, such as prejudicial beliefs, discrimination and disrespect. On the other hand, such emotions are generally not substantially scrutinized within liberal theory and policy-making. This essay suggests that there are more bad than good reasons for this. It illustrates, with the case of disability, how bracketing emotions out of reflections on justice and on the liberal subject may do more harm than good. In the concluding section, it considers shortcomings of the liberal conceptions of personhood and political status and it postulates that the difficulty of feminist and disability theorists in promoting their revised conceptions of status is partly due to powerful negative affective responses toward (people with) disabilities.

\section{Nasty Emotions and Why Liberals Do Not Think Enough About Them}

It is sometimes said that art speaks to the emotions whereas philosophy speaks to reason. This generalization does not withstand the examination of philosophical works using powerful metaphors and imagery, such as Plato's allegory of the cave [11], Thomas Hobbes's frontispiece [12], and John Rawls's thought experiment of the veil of ignorance [13], as well as highly cerebral art, such as Marcel Duchamp's ready-made Fountain [14]. Emotions also have an important place in the field of ethics. Although I had been interested in "moral emotions" such as compassion, love, concern, empathy and respect, I had been much less interested in analyzing "immoral emotions" such as disgust, hatred, envy or some debased forms of emotions that sometimes end up serving immoral purposes (such as pity, shame, or selflessness) even though they may serve moral purposes in other contexts. ${ }^{1}$ I did not

\footnotetext{
${ }^{1}$ For instance, other-regarding concern in the context of caring can be greeted as a virtue, but may also merge into a selfeffacing/sacrificing disposition (that may be connected to emotions) and criticized by feminists for making one vulnerable to exploitation [16].
} 
think that it was as urgent to understand the emotional hygiene of bad people as it was to praise and publicize the emotional insights of good ones.

There is, however, an obvious risk in ignoring the landscape of nasty emotions: we deprive ourselves of precious insights into how immoral acts occur and, indeed, how we may perpetuate them ourselves. A considerable portion of mainstream liberal theory falls prey to this blindness, and implicitly relegates the analysis of immoral emotions to the field of psychology or medicine. To some extent, it is justified: liberal theorists are not psychiatrists. However, pathologizing evil away may be a coping mechanism to avoid confronting the fact that these emotions are common or that the harms they engender are banal. It can also be a way to focus on "evils", or rather, moral emotional failures, that we are willing to fix, while opportunistically ignoring those that a reigning political ideology would protect. For instance, as reported by Nancy Fraser in her exchange with Richard Rorty on their disagreement over the role that a focus on recognition of cultural identities should have for the cultural Left, Rorty opined that:

[T]he post-Vietnam Left has already won the cultural revolution, having largely succeeded in dispelling stigma that used to mark racial minorities, women, and gays. Preoccupied with combating sadism, however, it neglected the fight against selfishness, allowing the rich to win the class struggle, as culture pushed economics aside. [17, p.23]

So it is not that liberals lack a language for nasty emotions, but only that this language lacks both scope and depth, so that only a few notions (e.g., discrimination and prejudice) are analyzed and dealt with. These comments also echo Judith Shklar's call to liberalism to pay attention to vices other than cruelty, as this vice alone is insufficient to capture many faces of injustice [4]. While such insightful criticisms are heard from time to time and influential political works have paid attention to many of the injustices overlooked by ideal theories [10], one can still be concerned that vices and immoral dispositions, attitudes and emotions do not get the attention they deserve in mainstream political theory. The gravity of this concern depends on how much further investigating them would enrich our understanding of (in)justice.

Part of the lack of attention to nasty emotions is attributable to the general distrust of emotions as a source of moral wisdom by philosophical traditions nested in the rationalist ideals of the Enlightenment [18], still reflected in the mainstream liberal understanding of the political subject pictured as exclusively rational and ideally immune to sentiments. ${ }^{2}$ One must distinguish this Kantian liberal strain from the praxis and rhetoric of liberalism, associated with the political left and empirically found to be more emotion-driven [19]. So-called "bleeding heart" liberalism has little to do with the liberal assumption "that the only thing we need to know about emotions is that, to build a well-ordered political system, we in fact need not know much about them at all" [8, p.127] and more generally that moral discernment will be clouded rather than sharpened by emotions [18]. Separating moral reasoning from emotions may be difficult if, as neurologist Antonio Damasio argues, "feeling [is] an integral component of the machinery of reason" [20, p.xii]. However, the rationalist may insist that it is still possible to construct an ideal standpoint for practical reason.

This same tradition has fostered a "dualistic, disembodied philosophy" that paid little attention to the phenomenality of the body and favoured, as Linda Holler argues, an ethics based on logos rather an ethics based on eros: that is, "a somatic, intuitive form of agency in which empathy, compassion, and care are the central moral qualities" [21, p.1]. This dissociation of moral duties from bodily awareness

\footnotetext{
${ }^{2}$ To be fair to liberalism, feminist criticisms of this picture of the subject as "male" have been criticized for failing to see that the liberal tradition has sufficient internal resources to respond to this criticism [cf. 22]. Conversely, to be fair to feminists and other critics of liberalism, much of their more recent critical work neither caricatures liberalism, nor does it fail to consider how liberal theories could be corrected rather than jettisoned [23,24]. It is nonetheless the case that the idealized figure of the independent and rational subject dominates everyday politics.
} 
would also contribute to explaining the scant attention paid to affective responses to "abnormal" embodiments.

As for the reticence to assess whether negative affective responses to disability may have influenced theorists discussing disabilities, directly or incidentally, it can probably be attributed to methodological views on what constitutes a valid mode of criticism. Analytic philosophers typically cringe before criticisms of a philosopher's suspected prejudices or biases, affective or not, whether supported by an analysis of the philosopher's personal life, including the cultural and academic context within which she was writing, or by her language, including her use of semantic fields, her argumentative structure, her methodology, and her choice of illustrations or thought experiments. In the words of John Finnis [25, p.65]:

The soundness of an answer to a particular question is never established or disconfirmed by the answer to the entirely different question of what are the physical, biological, and psychological preconditions and concomitants of the raising of that question... and of the proposing of that answer.

On the one hand, theorists are no less immune to being the unwitting vehicle of ideologies than any other social actor. On the other, it is equally easy to see how such ad hominem criticisms can quickly become unfair and even descend into name-calling. This is not to say that omissions cannot sometimes be meaningful (one thinks of Berlin's incisive criticism of philosophers' neglect of political phenomena [26]) or that personal confessions cannot illuminate one's philosophy (one thinks of JeanJacques Rousseau's "solitude" ${ }^{3}$ or Thomas Hobbes's confessed and assumed "timorousness"4). It means that such insights should be used with caution, lest they become as ideological as the ideology they attack, or fail to provide a reasonable and falsifiable argument. While they may surely inform or guide one's analysis without being explicitly referred to as an argument of their own, there would be little point in providing a philosophical argument if one could reject it by relying on the affective makeup, cultural context, or theoretical commitments of its author.

For instance, it seems unjustified to criticize a "strict compliance" theory of justice ${ }^{5}$ on the basis that an author is implicitly condoning certain kinds of injustice by paying exclusive attention to specific idealized social features. However, to echo Berlin, consider the scenario in which a group of philosophers charged with commenting on the trial of a slave examined the procedural fairness of his conviction for trying to run away rather than the greater injustice of his being a slave in the first place. The internal coherence and plausibility of their argument deserve to be recognized. Yet, it does not seem desirable to completely immunize their arguments from the criticism that they are under the grasp of a questionable ideology, translating into systemic discrimination affecting even academia. Berlin, for one, suggests that philosophers simply cannot invoke academic freedom to excuse themselves from directing their gaze in one direction instead of another. In some circumstances, Berlin goes so far as to suggest that this would be immoral:

[A] visitor from Mars to any British - or American - university today might perhaps be forgiven if he sustained the impression that its members lived in something very like [a Utopia-like] innocent and idyllic state, [because of the lack of attention by professional philosophers to political discord].

\footnotetext{
${ }^{3}$ For a discussion of how Rousseau's sense(s) of solitude affected his worldview and his philosophy, see Bronisław [27, p.251] and Jones [28, p.182-3].

${ }^{4}$ Which can be plausibly related to his rationally endorsed political submissiveness.

${ }^{5}$ A "strict compliance theory of justice", as John Rawls defines it [13, p.8] examines "the principles of justice that would regulate a well-ordered society" whereas a "partial compliance theory...studies the principles that govern how we are to deal with injustice."
} 
[This is] dangerous, because when ideas are neglected by those who ought to attend to them...they sometimes acquire an unchecked momentum and an irresistible power over multitudes of men that may grow too violent to be affected by rational criticism. ... [If] professors can truly wield this fatal power, may it not be that only other professors, or, at least, other thinkers (and not governments or Congressional committees), can alone disarm them? [26] ${ }^{6}$

Whether or not one agrees with Berlin, much concern about ad hominem or historicized criticisms would be assuaged if critics were clear on what their (meta-)criticisms accomplish or not. Such critical work is generally done by post-structuralists, examining how power structures pervade both political practice and philosophical theories [cf. 29,30]; hence, there is a legitimate concern that it does not regularly reach those working within the analytic liberal tradition.

I have so far given reasons for ignoring emotions in general, rather than reasons for not assessing the impact of negative emotions more specifically. Interestingly, most of the work by feminists, care ethicists, and disability theorists challenging traditional liberal theory and utilitarianism has reproached these schools for failing to feel appropriate moral responses (like care, love or empathy) rather than for feeling inappropriate ones (like vainglory or sadism).

For instance, I vividly remember an exchange between Eva Kittay and Jeff McMahan (as well as Peter Singer) who attended a conference at Stony Brook University in 2008 entitled "Cognitive Disability: A Challenge to Moral Philosophy". Feminists and disability theorists sometimes criticize utilitarian philosophers for failing to pay sufficient attention to the normative weight of affective responses nested in particular relations. After Kittay explains to Singer that she must regain emotional composure before she can intellectually engage with someone who has just compared her intellectually disabled daughter to a pig, Jeff McMahan vehemently argues that they should not be blamed for the liberal/utilitarian sin of all sins:

You know, Peter and I didn't come here to hurt anybody's feelings. We're here to try to understand things better. I think that Peter and I engage in a fair amount of voluntary self-censorship. I'm trying very hard not to say anything offensive, something hurtful. I'm profoundly averse to making people miserable.

\section{Kittay answers:}

I know you're not trying to hurt anyone's feelings. I know Peter isn't trying to hurt anyone's feelings. That's not what it's about. For me, it's not what I am experiencing, it's what your writings might mean for public policy. That's what concerns me. And that's not just about my daughter.

Kittay pointed to the necessity of properly relating emotionally to people with severe mental disabilities in order to properly assess their moral status. As she said during that exchange, "there is so much to being human. There's the touch, there's the feel, there's the hug, there's the smile,...there are so many ways of interacting." [31, p.407-9]

The external reviewer of this essay commented that, in the examples I give, Kittay does not argue in favour of "feeling" fittingly as much as she combats the stereotype that feminist or disability theory is only a matter of "feeling". Indeed, Kittay makes it clear she is concerned with the political implications of McMahan's views and thinks little of his commiseration, but this is because commiseration is the

\footnotetext{
${ }^{6}$ The "political turn" in philosophy operated by John Rawls two decades after Berlin's inaugural lecture renders Berlin's concern over the lack of attention for political phenomena less topical, but Berlin's underlying criticism may still be applied mutatis mutandi to idealized or ahistorical political theory or other theoretical grave omissions or neglect by those sharing his outlook.
} 
wrong affective response, and is directed at the wrong person (i.e., Kittay, instead of her daughter and other people with intellectual disabilities.) Therefore, I agree with the reviewer that Kittay is concerned with policy, but I do not think that she discards the importance of appropriate feelings. My understanding is that she criticizes McMahan and Singer for failing to adopt certain affective dispositions or attitudes without which one's epistemic stance toward an object of philosophical reflection (in this case, people with intellectual disabilities) is inherently limited.

It is probably the case that someone can be made morally wiser both by being shown how to emote proper attitudinal responses to various situations and by reflecting on the "nasty emotions" that prevent him from doing so. To illustrate, Charles Dickens' Scrooge's change of heart occurred as he was simultaneously made aware of his vices by the Ghost of Christmas Yet to Come, and of how it used to feel, and would feel, to endorse a different set of affective responses by the two previous Ghosts. ${ }^{7}$

It is not a coincidence that philosophers like Cora Diamond [32] or Judith Shklar [4] refer to literary characters in their analysis of various vices, "blindnesses" or poor affective responses. We owe it to great writers of fiction to teach us the parameters of "nasty emotions". It is tempting to suggest that they approach the issue of negative emotions and evil more generally from a descriptive stance (good literature is sometimes said to provide readers with a better understanding of human nature), whereas theorists and policy-makers often approach them from a corrective stance. Since a corrective stance does not necessarily need to investigate the affective dimensions of behaviours it can simply prohibit, nasty emotions may be erroneously caricatured, and some may receive more attention than others (e.g., those that can be effectively criminalized or medicalized and cured). Thus partially ignored, nasty emotions shape and consolidate individual prejudices and systemic discrimination. The next sections offer a glimpse into the nature and impact of such nasty emotions toward disabilities.

\section{Suppression, Anxiety and Fear of Vulnerability}

There are a good number of nasty emotional responses vis-à-vis disabilities that could be discussed. For instance, the (often self-serving) pity addressed to "tragically" unlucky disabled people; the anger or resentment at them for failing to carry their weight within the cooperative venture that our society is conceptualized to be; the fear that our political order will crumble if these subjects' peculiar mental and physical traits render them unamenable to being punished if they defect or to being held accountable if they do not properly participate. This latter, Hobbesian, fear is not directed at disabled people per se, but at the threat that their request to belong to the political order poses to the parameters of this order and to what it means to be a political subject. Liberals are, almost by definition, afraid of losing their liberty. They are afraid that the state takes it away from them, afraid that their fellow citizens make intrusive demands on the use of their time, and afraid of wasting their lives, because it would be entirely their fault if they did.

This fear (or a reflection of such a fear) may be what Mael Lemé's artistic creation seeks to inspire in his audience, by creating a "Foucauldian monster".

\section{Michel Foucault's "Monster" and Mael's Creation: France-e(s)t-Mael}

As Foucault explains in his lectures at the Collège de France, in 1974-5 published under the title "The Abnormals":

The monster...contradicts the law. He is the breach/offence [infraction].... And yet, while being an offence, he does not trigger a legal response... The monster does not call for a response from the law itself, even if he violates the law by existing. The response will be [non-legal]: violence, a desire to suppress pure and simple, or else medical care, or pity. [33, p.52 (my translation)]

\footnotetext{
${ }^{7}$ I am borrowing this example from Cora Diamond [32], whose language echoes the argument that Kittay made to Singer and McMahan.
} 
The "monstrous" is the notion qualifying an obstacle to the law, it is a being to which legal norms cannot apply, it escapes the reach of legal authority and political power. The King, standing above the law, for instance, would be a "legal monster" [33, p.87-8]. Similarly, if individuals do not possess (enough of) the needs, capacities and propensities for social participation on which, for instance, modern theories of justice from Thomas Hobbes's [12] to John Rawls's [13, p.15-9] capitalize, they cannot be part of the social contract. This is because their differences prevent them from being cooperative, accountable, participants in society, conceived as a joint venture.

Paying attention to the theoretical figure of the "monster" brings the focus on ideological motivations for excluding "abnormal" beings and then enables critical thinkers to reveal hidden legalistic modes of exclusion. Detecting the monstrous, however, requires an active effort, as we naturally conceal it to enhance our sense of control, over society and over our selves. The monstrous is an essentially peripheral legal notion, in the sense that it challenges the limits of the law. Mechanisms to deal with the monstrous, Magrit Shildrick suggests, are akin to coping mechanisms to alleviate anxiety: the anxiety caused by the monster's challenge to the boundaries of our bodies, and of our legal order and subjecthood [30]. Even though law cannot apply to the "monstrous", constructing the (extra-legal) parameters of the monstrous can be a form of power or violence to which legal actors can participate by applying rules that cast certain persons out of the legal realm, while leaving their oppressive underlying foundations intact and their legitimacy unquestioned. ${ }^{8}$

Mael's creation is a "transatlantic siamese hermaphrodite" being, composed of his audio-visual presence on a tablet attached to a dancer with tetraplegia, France Geoffroy, who will perform a choreographed dance in her wheelchair. Ms. Geoffroy will perform in Montreal while Mael will attend the exhibition from his living room in France. He will furthermore control some of her movement by sending signals through electrodes stimulation patches on the dancer's arms. This complex form of embodiment, including a dual mind, raises both legal ${ }^{9}$ and metaphysical issues [30]. However, Mael's creation of an unexpected form of embodiment through technological means may also create another kind of negative emotional reaction: anxiety. This general reaction, it has been argued, would unfortunately be a common reaction to "abnormal"10 embodiments. I turn to it now.

\section{Anxiety and Suppression of Different Bodies}

In her book Dangerous Discourses of Disability, Subjectivity and Sexuality, Magrit Shildrick examines the anxiety caused by disabled people and the cultural disavowal of their anomalous bodies [30].

Shildrick makes the argument, familiar to critical legal theorists, that the law "disavows" anomalous bodies while claiming the "rationality, impartiality and consistency" on which it bases its authority [30, p.103]. However, a specific ideological understanding of the legal subject and justice underlies these basic claims. Legal actors, such as judges, will not question these ideological assumptions. Their assessments or judgments are not even confronted with the anomalous bodies put before them; instead, their understanding of the "liberal subject" mediate the very recognition of these beings, who do not exist as legal subjects outside of the language used to apprehend their existence.

The mainstream conception of the "legal subject" corresponds to that of the "liberal subject" and is characterized by these qualities: autonomy, self-sufficiency and relative invulnerability and independence. ${ }^{11}$ Why can judges, legislators, law professors or other legal actors not think outside of

\footnotetext{
${ }^{8}$ This is reminiscent of Steven Lukes's argument on the importance of detecting hidden conflicts of interests in his seminal work Power: A Radical View [34].

${ }^{9}$ For instance, judges had to normalize the embodiment of Siamese twins by conceiving them as two distinct beings before deciding whether it was permissible to kill/let die one of them in order to allow the other one to live [35].

10 I use the word "abnormal" in this text in relation to Magrit Shildrick's and Michel Foucault's own use of it. The reader should be aware that it may carry harmful connotations when it qualifies disabilities in other contexts [cf. 2].

${ }^{11}$ For a critical description of the dominant liberal understanding of the "legal subject", see for example, Martha Fineman [37] and Jennifer Nedelsky [38].
} 
this paradigm? Why should they fetishize ${ }^{12}$ legal procedures, tests, rules, conditions and assumptions that do not fit these anomalous bodies?

Shildrick suggests that disabled people pose an anxiogenic threat to our identity. Her understanding of anxiety is related to physical and sexual encounters. She roots it in psychoanalytic theory suggesting that our Western aversion to touch is related to our fear of disturbing the fragile "illusion of singularity and corporeal unity" that keeps our identity differentiated from others. Touching another body that we do not control as we control ours awakens our "incompletely repressed experience of infantile dis-organisation". In other words, these bodily contacts threaten the sense of our bodily boundaries or of our distinct selfhood. The threat to our distinctiveness is even more acute when the body interacting with ours is anomalous, "other" rather than "same" [30, p.91-2]. In her words:

My argument is that if any coming together of bodies, and more specifically the intercorporeality of much sexuality, is encompassed within an implicit anxiety about the loss of self-definition, then that anxiety - which operates within us all - is at its most acute where the body of the other already breaches normative standards of embodiment. [30, p.84].

When she discusses how anomalous bodies "transgress" the legal order, Shildrick turns to a Foucauldian model of power that "gives little credence to psychic factors" [30, p.87], but maintains her hypothesis that disabled bodies represent a source of anxiety within the legal order. However, when we move to the legal sphere where disabled people meet rigid legal frameworks conducive to exclusion, rejection, or assimilation, a psychoanalytical understanding of anxiety may be helpfully complemented with an institutional kind of anxiety. Members of the legal elite, like other social actors who are part of socially privileged groups, have an incentive to maintain the status quo. This criticism of a possible underlying motivation for rejecting otherness points to anxiety related to a threat to one's socially dominant status rather than anxiety related to a threat to one's self, but I suspect it is at least as familiar to theorists of injustice.

Lawyers will intuitively answer to Shildrick that Western legal systems have no difficulty treating, for instance, amputees as legal subjects for the purposes of contract or tort law. It does seem that our legal systems have become more apt at recognizing the legal subjecthood of people with physical disabilities. Of course, injustices remain rampant: issues of exclusion and injustice with regard to physical disabilities and some mental illnesses or disabilities typically have to do with unfair measures of accommodation, support, integration or compensation. However, the very status of disabled people qua full legal subject, or qua moral person, is much more commonly challenged or ignored with regard to cognitive impairments.

Shildrick's work is abstract and does not provide abundant concrete illustrations. For instance, when she discusses legal subjecthood, her main example is the case of conjoined twins for whom a surgery would allow only one of them to survive. In this case, courts have naturally assumed that they were dealing with two distinct persons, without considering the possibility they would be facing a single legal subject. This is an interesting issue, although only a small group of scholars trained in metaphysics would be inclined to problematize this assumption [35]. An example of a more intuitively revulsive scenario would be that of parents who are deprived from the custody of their child because they are blind, quadriplegic or otherwise severely physically disabled [36]. Even though the law would eventually recognize that they have been victims of discrimination after a gruelling legal battle, the fact that a policy even allowed for a temporary deprivation of custody on the basis of disability (instead of less intrusive measures to verify that a child lives in a safe environment), arguably correlates with a failure to recognize someone's equal legal and moral status. ${ }^{13}$ This example, I note, supports the view that people with mental illnesses or intellectual disabilities are at greater risk of being excluded from the legal order, since their rate of losing a child's custody is vastly superior [40].

\footnotetext{
12 On institutional and structural fetishism, see Roberto M. Unger [39, p.129].
} 
Since intellectual disabilities pose a greater risk to one's personhood, it is important to examine how anxiety may also be induced by the challenge that people with disabilities pose to our social organization, as understood within mainstream liberal theory. I turn to this issue in the next section.

Shildrick's hypothesis on anxiety related to "abnormal embodiment" nonetheless remains pertinent to explain people's emotions toward disabled people. Even when these affective reactions do not threaten the legal or moral status of disabled people directly, they can do so indirectly, for instance, if they influence the various social actors (nurses, social workers and other civil servants and policymakers) intervening at different stages of the aforementioned custody cases.

Finally, I do not see why both the anxiety that Shildrick describes (caused by experiencing a different body making us question our own embodiment), and the ethical prescription she makes (understanding one's own body as fluidly changing and acquiring and losing abilities) could not apply to intellectual disabilities as well. ${ }^{14}$

\section{Fear and Exclusion of Different Minds}

The traditional liberal subject is not quite human: he was never young and dependent, nor will he ever be old and frail. He spontaneously came into being as a statistically normal mentally and physically able man, as ideal subjects tend to do. He is strictly self-interested, autonomous and able to develop a conception of the good life without help. He is self-sufficient and relates to others through a bargaining paradigm. This liberal fiction reduces human moral agency to the particular role of a "contractor" (from 9am to 5pm, I should add, as his family and personal attachments are of lesser concern to the political order and belong to the category of activities he may pursue within the sphere of negative freedom he has negotiated with his fellow businessmen).

People who are in a situation of dependency, perhaps because of disabilities or old age, remind us of the vulnerability characterizing our own life, how we are needed and need others. The social dimension of disability also makes it obvious that, just as socially constructed barriers can disable otherwise capable individuals with a biological impairment, our "independence" is in fact a myth: we could not develop or exercise our capacities independently from others. Disabled people, when they refuse to be characterized as more dependent than any other body-able people, implicitly threaten the liberal myth according to which our independence is a gateway to freedom. People with very severe impairments also remind us more fundamentally of our finitude, and of the fragility of our happiness. Feelings of fear, despair, self-pity, and shame can lead to an attempt to hide our own fragility. Even nastier emotions, like cruelty and delight in our good fortune and the misery of others, can motivate people to embrace the "tragedy model" of disability, by casting misery upon others. By failing to embrace our dependent nature and moulding our political and legal order as though human beings were liberal contractors, it is possible that we become transfixed by this illusion and avoid dealing with our ineliminable vulnerability.

A variety of feminists and disability theorists have been suggesting that we replace the liberal myth of independency by a more realistic and desirable understanding of personhood. For instance, political subjects may be motivated by other-regarding concern; they would be inter-dependent at every stage of their lives, to different degrees; they would need to engage in social roles in order to develop a conception of the good life and to live a flourishing life. These suggestions for remodelling the liberal "political subject" and, more generally, mainstream understandings of moral agency, so that it would better confront and respond to vulnerability are not new, but nor are they old. While the work of early care ethicists such as Nel Noddings [42], Annette Baier [43], Eva Kittay [31], and Sara Ruddick [44],

\footnotetext{
${ }^{13}$ An argument to that effect could be that ignoring or flouting the fundamental rights or entitlements (such as the right to be a parent or to raise one's child, as long as this is in the child's best interests) of a group of people can sometimes correlate with a denial of their status as an equal legal subject.

${ }^{14}$ Cognitive differences may also threaten our sense of self. Sexual intimacy with a cognitively impaired individual, as well as the legal policing of such encounters, seem to involve more, rather than less, affective prejudices [41].
} 
date back to the 1980's, care ethics and germane scholarship in law and philosophy has really flourished into full-fledged theories of justice in the first decade of the $21^{\text {st }}$ century. ${ }^{15}$ But in spite of this promising emergence of an awareness of the need to account for human vulnerability and interdependency, the conception of the traditional liberal subject still sits at the heart of political theory and practice.

Of course, one explanation is that the feminist plea to export an interdependent or caring outlook on social interactions into the political and the legal realms is wrongheaded. ${ }^{16}$ Assuming the feminist criticism is right, however, another explanation is simply that common sense and ordinary social practices are only gradually catching up with these $21^{\text {st }}$ century insights into moral status. I would not dare to evaluate the practical extent of this "progress" (cherry-picking examples where our legislators think like relational theorists or judicial decisions where an outdated vision of the legal subject leads to unfairly exclusivist results would prove little). My interest here is rather to lay the ground for the hypothesis that certain negative emotions may contribute to a resistance to moral progress. It is plausible, though hard to prove, that the nasty emotions mentioned previously, such as fear, shame and anxiety, feed a broad denial of our vulnerability and dependency. This affective vector is probably a key antagonist force with which revisionist political theorists must contend.

\section{Scholarly Prejudices}

The comments above examine how anxiety and denial of vulnerability may affect the fundamental and far-reaching conceptualization of the liberal subject. However, ignoring negative affective states toward (people with) disabilities may also impoverish the quality of narrower ethical discussions. A theorist may, for instance, and probably unwittingly, perform an argumentative sleight of hand, or overlook an important moral dimension of a problem, in a way that both author and readers will ignore because they share certain affective prejudices. Let me illustrate.

Licia Carlson's robust criticisms of philosophers writing on disabilities provides a good instance of the sort of critical work that would bring this issue to the light of day. For instance, she analyzes how Peter Singer used the word "imbecile" interchangeably with "permanently retarded human" in a 1974 article [45], and how Vinit Haksar, in his book on perfectionism and egalitarianism [46], analyzing the status of "idiots", refers to idiocy without clearly defining it, and includes language such a "idiots and their like" and "[t]he congenital idiot is a parasite". It should be noted, however, that "idiocy" and other terms now considered to be disparaging were legal terms of art in English and American law well into the $20^{\text {th }}$ century. Jeff McMahan's 1996 article, "Cognitive Disability, Misfortune, and Justice" [15], examines whether "cognitively disabled" individuals should be compensated for their disability, and designs thought experiments that compare characters such as "Bertrand Russell" with "the Dullard" and how unfortunate they would respectively be to become "contented idiots". McMahan uses the term "moron" in another thought experiment in the same article. Carlson multiplies the examples: Joel Feinberg refers to "human vegetables" and Isaiah Berlin, to "idiots" as well [30, p.109-112].

Some of these philosophers are theoretically committed to challenging the moral and political status of people with intellectual disabilities. The concern I express here is not that their views are mistaken (they may be, but this needs to be argued by engaging with their arguments and showing where one believes they went wrong). The concern that some disability theorists have is that these theorists are 1) themselves prey to affective prejudices or 2) make use, consciously or not, of these affective prejudices to sway their readership. While Carlson is more concerned with the "stigmatizing and oppressive effects" of this problematic terminology, she refers to the aforementioned issue, and

\footnotetext{
15 Influential works include Alasdair Mcintyre's Dependent Rational Animals: Why Human Beings Need the Virtues [47], Virginia Held's The Ethics of Care [48], Eva Kittay's Love's Labor [49], Michael Slote's Moral Sentimentalism [50] and Daniel Engster's The Heart of Justice [51].

${ }^{16}$ As my friend, Dr Aruna Nair, put it, "might it not be much nicer to feel like an interdependent and vulnerable being at one's dinner table at home, and much nicer to feel like an autonomous and boundaried subject at the barrel of a gun (in a prison, in a court)?"
} 
wonders how far "this language actually taps into the reader's own prejudices and impressionistic knowledge of what conditions like idiocy and imbecility mean" [29, p.112].

As she pithily suggests later, "[i]nterestingly, [Peter Singer] did not choose the example of your hopelessly senile grandma to make his case against speciesism" [45, p.143]. Instead, Singer made his point with intellectually disabled people. However, few of us actually have a relationship with an intellectually disabled person, most of us are acquainted with nasty caricatures and routinely engage in inappropriate affective responses (disgust, fear, pity before a tragedy, etc.) when contemplating severe intellectual disabilities. Is there any chance, therefore, that Singer's readership would be nudged away from considering that Singer's argument may have missed something of importance if it entails that grandma needs to be sacrificed? Is the argument earning some purchase on the basis of affective prejudices? Similar, uncomfortable, questions can be asked when disabilities are being discussed in other theoretical and practical fora so that other kinds of discourses (e.g., judicial or political) do not capitalize on affective prejudices.

One may respond that Singer's lexical choices aimed at avoiding another sort of prejudice that he was denouncing in his writings: speciesism. Still, this only means that critical scrutiny should run both ways; affective prejudices generally cumulate rather than cancel one another. Indeed, one would expect that a more empathetic person would be more responsive to both animals and people with cognitive disabilities. Philosophers should ideally scrutinize the rhetorical strategies they use so that they do not trick readers by tapping into their unquestioned beliefs or prejudices, may they be speciesist or ableist. Self-policing would also avoid heated confrontations, although Carlson's wellresearched work shows that such critique can also be made externally in a relatively collegial way.

\section{Failing to Engage Affectively}

Singer's and McMahan's controversial writings prompt me to add that moral philosophers need not only worry about their negative affective responses to disabled people, but also about the sort of affective interactions they may need to have with disabled people in order to learn how to properly assess the value of a "disabled life". I have heard some outrageous ableist comments at different stages of my career; they generally surfaced when acquaintances or senior colleagues let their guards down and privately bantered. An Aristotelian told me he believed in elitist schooling systems segregating the "dumber" ones into a sure path to further social exclusion. A Kantian confessed his eugenic preferences and believed that my research on the moral status of persons with severe mental disabilities was "decadent". A tipsy Hobbesian told me that he would put severely mentally disabled people on a row-boat to see how well they fare when left to their own devices. In vino veritas.

While philosophers are not immune to negative affective responses, they more often do not care enough about disabled people to dislike them actively, which raises a different concern. They may more plausibly be criticized for methodically refusing to engage affectively with people with mental disabilities than for entertaining negative emotions toward them. While Carlson would criticize renowned theorists for unreflectively using an antiquated language, and Eva Kittay would interpret their sloppiness as shrinking from their "epistemic responsibility" [31, p.400], most of these philosophers would probably adjust their terminology when and if asked to do so. Political correctness would not change their indifference however. It would show that they do not have hostile attitudes toward people with mental disabilities. (Their rigorous commitment to their philosophical views may be politically hostile to people with disabilities, but they are not affectively hostile.) This is the realization that disability activist Harriet McBryde Johnson had when she wrote, after meeting the "evil" Peter Singer: "I think his ideas are new, in a way. It's not old-fashioned hate. It's a twisted, misinformed, warped kind of beneficence. His motive is to do good" [52]. The worry is therefore about a potential affective indifference toward cognitively disabled individuals, subtly manifesting itself through rhetorical manoeuvres and argumentative assumptions. Indifference toward a particular group of people, or toward the particular relations of oppression characterizing their place in society, can be as strong a pillar of discriminatory practices as are actively hostile attitudes. This indifference may in 
some cases be fed by an ableist assumption that disabled people are necessarily worse off or by what Simo Vehmas calls an "intelligist" assumption, which assumes that intelligence plays an essential role in one's quality of life and that less intelligent people's lives are less valuable [53].

Philosophers who challenge the moral status of people with disability would certainly reply that they are not "indifferent" or that their disposition to not engage affectively with the entities whose status they are trying to determine is a way to avoid a bias in favour of human beings. The argument then reaches a dead-end for it is very hard to argue that someone's intuition about what should play the role of a bedrock in moral philosophy is mistaken. Some may criticize philosophers like Singer for training themselves to be a little bit less human while entertaining the belief they are virtuously training themselves not to fall prey to a "human prejudice"17. I personally think that he pays far too little attention to the value of certain relations, and far too much attention to non-relational individual properties, though I will not argue this here. Cora Diamond, to give another example, writes about the importance of imagination in ethics and that the value of being human can best be seen from an imaginative point of view. She considers Charles Dickens' character Scrooge and writes:

[Scrooge] will not be able to respond to the sufferings of the Cratchits until he comes to have, in his perception of their lives and their fate, a full imaginative sense of his own mortality, until he can live in the present and acknowledge his own past. That opening of the heart, which for Dickens is tied especially to Christmas, is inseparable from a live sense of oneself as, with others, bound towards death, of others as one's 'fellow passengers to the grave'. The viewing of other people as 'another race of creatures, bound on other journeys', is an expression of one's having suppressed or rejected, rather than imaginatively owned, one's own being human [32, p.49].

However, when Kittay offered to take Singer and his students on a field trip to meet people with cognitive disabilities, Singer declined this Dickensian journey as morally pointless. He urged Kittay to skip the affective and imaginative engagement part and cut to the chase by telling him what he would learn without taking the journey [31, p.405]. At this point, a philosopher of disabilities may only answer: what would I learn from comparisons between properties possessed by anonymous receptacles independent of their relations and communities, including those stemming from their embodiments and from sharing a fate with others?

Changing people's minds on whether and how to engage with other human beings (or animals, or trees) through one's philosophical work is no easy task, and perhaps one best attempted from a psychiatrist's armchair than through philosophical conversations. One reason for this is that people's pretheoretical commitments are often a matter of integrity: they hold on to these commitments steadfastly to make sense of themselves. A controversial question is whether the commitment of philosophers who are parents or siblings of people with cognitive disorders or disabilities is not only moral, but also an epistemologically precious moral insight important to share with those who take no part in these relations. Accounts of integrity differ on the question of whether integrity is a virtue or implies moral constraints [55]. Caring parenthood seems, prima facie, like a more likely candidate to make the case that some pretheoretical commitments are morally informative than, say, an aesthetic taste for symmetrical arguments. As Peter Byrne puts it, reflecting on Singer and other philosophers from the standpoint of his role of father, including as a father of a child with autism:

The grammarian will work backward and forward from intuitions concerning the grammaticality of sentences to principles. Principles will have to conform to what native speakers take to be centrally grammatical and ungrammatical. But the grammarian's principles will not have to conform to intuitions about sentences which are borderline cases. Indeed the principles established by reference to the central cases will help sort out the members of this class.

\footnotetext{
${ }^{17}$ See Bernard Williams's [54, chap.13] defense of this "prejudice" as a human peculiarity.
} 
The analogy between the grammarian and the moral philosopher quickly breaks down. What stands behind my conviction that killing a newborn baby is murder is not an intuition on a par with a raw feel that an odd-looking sentence is nonetheless grammatical. For if I gave up that conviction (...) my view of myself and my world would change dramatically [56, pp.46-7].

Finally, one may defend utilitarians reaching Singerian conclusions by objecting that they may be affectively invested in the well-being of people with disabilities and still believe that they would be better off dead. First, I concede that in some cases, people can better off dead, but this essay is not considering this small group of people. It is rather concerned about ableist assumptions and affective responses that would drive one to categorize people who have a worthwhile life in that group. Second, any discussion of whether people would be better off dead always happens in the shadow of another discussion about who should have the authority (and in which circumstances) to act upon such judgments. The instances of beneficent killing would therefore be rarer than the objector supposes in practice: it is insulting to someone's autonomy to tell them compassionately that they should die now (or damaging to their self-esteem, to say the least, to tell them their parents should have ended their lives). As for parents ending their future disabled child's life, they are generally not acting out of beneficence. They are concerned about the burden they will have to shoulder without proper social support. Alternatively, they may truly feel that "this is not a life to give someone". This alternative, however, invites me to give a third reply to the objection, which is that beneficence justifying killing or aborting is not immune to the ableist assumptions outlined above. ${ }^{18}$ Fourthly, the notion of "beneficence" may be taken to have the kind of (positive) affective dimension I am discussing here. It would make it closer to conceptions of empathy or concern. However, a "beneficent" utilitarian probably understands the notion only as implying a duty to maximize well-being in the world. She might also endorse a theory of identity according to which it is not wrong to end an infant's life because "it" is not yet a person and it has no strong connection with its future self (i.e. the "beneficence" justifying ending the infant's life would not be directed at the infant). This non-affective understanding of beneficence would therefore not address my criticism of indifference, since one can be affectively indifferent and beneficent in the utilitarian sense. Indeed, this brand of beneficence may require one to deliberately suppress one's affective responses.

\section{Conclusion}

I am not claiming that occurrent affective responses are always necessary to act morally. They can certainly be inappropriate or paternalistic in some contexts. Similarly, it is not necessarily beneficial to pay attention to "nasty emotions" toward disabilities. Acknowledging such emotions as proper topics of discussion in the public sphere can go wrong and be perceived as condoning such emotions as legitimate bases for nasty claims. Ignoring nasty emotions is also a common strategy of protection for people who are members of various oppressed groups or whose mental or physical traits defy expectations of normalcy. I do not mean to imply, therefore, that our social institutions and theorists of justice should systematically ignore or inspect negative affective responses or give a central political role to positive ones. I only suggest that we currently pay unjustifiably little attention to them.

Let me situate this essay vis-à-vis Mael Le Mée's work. The starting point of this reflection was a series of conversations with an artist in which we considered how the notion of disability could be presented as a work of art. This transdisciplinary exchange prompted me to reflect on prejudiced or negative emotions sometimes felt toward disability, since I worried that an audience would react in this way to Le Mée's creation. Namely, as I was uncomfortable with an artistic project that would employ or mimic people with disabilities in an exhibition designed to provoke potentially negative

\footnotetext{
18 These replies to the imagined objection are very brief; properly fleshing them out would require me to deal with utilitarian arguments, whereas the focus of this essay is the (lack of) affective dimension of such arguments. In any case, I would have little to add to what Simo Vehmas [57] convincingly wrote on the points I raise.
} 
affective reactions in the audience. Indeed, I found it insurmountably exploitative. However, various artistic endeavours by members of the disability community and of other oppressed groups, such as Aboriginal peoples and African-Americans, have powerfully appropriated prejudiced terms, visuals and emotions in art. Not every use of "disability" or "disabled people" as artistic objects or subjects is thereby necessarily oppressive. In fact, such art may be part of a liberationist movement. It is nonetheless important that these artistic expressions - and the intention to cause particular affective reactions - originate from the members of socially oppressed ${ }^{19}$ groups themselves, in order not to usurp their voice. One might also argue that negative affective responses are most problematic when they are unconscious and unacknowledged. Therefore, an artistic project that would bring these negative emotions to the awareness of its audience would have the merit of inducing a modicum of self-reflection.

This project raised other interesting questions regarding the ethics of art. Namely, do artists who primarily intend to trigger positive emotions (such as awe, wonder or admiration) or virtuous inclinations (such as a healthy curiosity or empathy) in their audience, still have a responsibility to sound out the assumptions at work in the culture where they display their art, or probe the origins of their artistic impulse, or keep their own good faith in check? Surely, artistic expressions should not be submitted to the same exacting scrutiny as political or legislative actions. The specific degree and kind of ethical scrutiny art might undergo is a controversial matter that I did not consider here as my role was not to validate Le Mée's independently authored work. The goal of our exchange was rather to mutually inspire one another. The discomfort that stemmed from our discussions was fruitful, as it begged the question as to whether well-meaning liberal thinkers too often turn away from "nasty emotions" and formulate theories that lack corrective structures to truly deal with them. As such, to paraphrase Nietzsche's statement on philosophical writing, this essay is in part a personal meditation [57], though I hope it may also serve as an invitation to revisionist liberal theorists to similarly introspect.

\section{List of References}

1. Wolfensberger W. Social role valorization: A proposed new term for the principle of normalization. Mental Retardation. 1981; 21: 234-9; republished in Intellect Dev Disabil. 2011; 49(6): 435-40.

2. Silvers A. A fatal attraction to normalizing: treating disabilities ad deviations from speciestypical functioning. In: Erik Parens Editor. Enhancing Human Traits: Conceptual Complexities and Ethical Implications. Washington (DC): Georgetown University Press; 2000.

3. Lemée M. Various artistic projects listed on personal website (http://www.mael-lemee.org)

4. Schklar J. Ordinary Vices. Cambridge (MA): Harvard University Press; 1985.

5. Nussbaum M. Upheavals of Thought: The Intelligence of Emotions. Cambridge (UK): Cambridge University Press; 2001.

6. Nussbaum M. Hiding From Humanity: Disgust, Shame, and the Law. Princeton: Princeton University Press; 2004.

7. Nussbaum M. Political Emotions: Why Love Matters for Justice. Cambridge (MA): Harvard University Press; 2013.

8. Andrew A, Ross G. Mixed Emotions: Beyond Fear and Hatred in International Conflict. Chicago: University of Chicago Press; 2014.

9. Anderson E. What is the point of equality? Ethics. 1999; 109(2): 287-337.

10. Young IM. Justice and the Politics of Difference. Princeton: Princeton University Press; 1990.

11. Plato. The Republic. Various editions. Book VII, 514a-520a.

12. Hobbes T. Leviathan. Various editions.

13. Rawls J. A Theory of Justice, Revised edition. Cambridge: Belknap Press; 1999.

\footnotetext{
${ }^{19}$ I use the notion of oppression in the multi-facetted sense explained by Young, including marginalization, powerlessness and exploitation [10, chap.2].
} 
14. Duchamp M. Fountain. Work of art, first exhibited at the Society of Independent Artists, in 1917, New York.

15. McMahan J. Cognitive disability, misfortune, and justice. Philosophy and Public Affairs. 1996; 25(1): 3-35.

16. Dimock S. Why all feminists should be contractarians. Dialogue. 2008; 47(2): 273-290

17. Fraser $\mathrm{N}$. Why overcoming prejudice is not enough: a rejoinder to Richard Rorty. Critical Horizons. 2000; 1(1): 21-28.

18. Little MO. Seeing and caring: the role of affect in feminist moral epistemology. Hypatia. 1995; 10(3): 117-137.

19. Pliskin R, Bar-Tal D, Sheppes G, Halerin E. Are leftists more emotion-driven than rightists? The interactive influence of ideology and emotions on support for policies. Pers Soc Psychol Bul. 2014; 40(12): 1681-1697.

20. Damasio AR. Descartes' Error: Emotion, Reason, and the Human Brain. New York: G. P. Putnam's Sons; 1994.

21. Holler L. Erotic Morality: The Role of Touch in Moral Agency._New Brunswick (NJ): Rutgers University Press; 2002.

22. Nussbaum M. The Feminist Critique of Liberalism, The Lindley Lecture, University of Kansas, Department of Philosophy. 1997 March 4.

23. Christman J, Anderson J, eds. Autonomy and the Challenges to Liberalism: New Essays. Cambridge: Cambridge University Press; 2005.

24. Mackenzie C, Stoljar N, eds. Relational Autonomy: Feminist Perspectives on Autonomy, Agency, and the Social Self. Oxford: Oxford University Press; 2000.

25. Finnis J. Natural Law and Natural Rights. 2nd Ed. Oxford: Oxford University Press 2011.

26. Berlin I. Two concepts of liberty, 1958. In Berlin I, editor. Four Essays on Liberty.

Oxford: Oxford University Press; 1969.

27. Bronisław B. Rousseau, solitude et communauté. Brendhel-Lamhout C. translator. Paris : Editions de l'Ecole des Hautes Etudes en Sciences Sociales; 1995.

28. Jones JF. Rousseau's Dialogues: An Interpretive Essay. Genève: Droz; 1991.

29. Carlson L. The Faces of Intellectual Disability: Philosophical Reflections. Bloomington : Indiana University Press; 2010.

30. Shildrick M. Dangerous Discourses of Disability, Subjectivity and Sexuality. London: Palgrave Macmillan; 2009.

31. Kittay EF. The personal is philosophical is political: a philosopher and mother of a cognitively disabled person sends notes from the battlefield, in Kittay E, Carlson L. editors, Cognitive Disability and Its Challenge to Moral Philosophy. Wiley-Blackwell; 2010.

32. Diamond C. The importance of being human. Royal Institute of Philosophy Supplement. 1991; 29: $35-62$.

33. Foucault M. Les Anormaux : Cours au Collège de France, 1974-1975 Paris: Seuil/Gallimard; 1999.

34. Lukes S. Power: A Radical View. London: Macmillan Press; 1974

35. Savulescu J., Persson I. Conjoined twins: philosophical problems and ethical challenges. J Med Philos. 2016; 41(1): 41-55.

36. Olson ET. The metaphysical implications of conjoined twinning, Spindel Supplement. South J Philos. 2014; 52: 24-40.

37. Fineman M. The vulnerable subject: anchoring equality in the human condition. Yale J.L. \& Feminism. 2008; 20(1): 1-23.

38. Nedelsky J. Law's Relations: A Relational Theory of Self, Autonomy, and Law. Oxford: Oxford University Press; 2013.

39. Unger RM. What Should Legal Analysis Become? London, New York: Verso; 1996.

40. National Council on Disabilities. Rocking the Cradle: Ensuring the Rights of Parents with Disabilities and Their Children. Washington (DC): National Council on Disabilities; 2012 
41. Razack S. From consent to responsibility, from pity to respect: subtexts in cases of sexual violence involving girls and women with developmental disabilities. Law Soc Inq. 1994; 19(4): 891.

42. Noddings N. Caring: A Feminine Approach to Ethics and Moral Education. Berkeley: University of California Press; 1982.

43. Baier A. Moral Prejudices: Essays on Ethics. Cambridge: Harvard University Press; 1994.

44. Ruddick S. Maternal Thinking: Toward a Politics of Peace. New York: Ballentine Books; 1989.

45. Singer P. All animals are equal. Philos Exch. 1974; 5(1): Art. 6.; reprinted in LaFollette, $H$. (ed.). 2007. Ethics in Practice: Third Edition. Malden, MA: Blackwell. p. 171-180.

46. Haksar V. Equality, Liberty and Perfectionism. Oxford: Oxford University Press; 1980.

47. McIntyre A. Dependent Rational Animals: Why Human Beings Need the Virtues. Chicago: Open Court; 2001.

48. Held V. The Ethics of Care: Personal, Political, Global. Oxford: Oxford University. Press; 2006.

49. Kittay EF. Love's Labor: Essays on Women, Equality and Dependency. New York: Routledge; 1998.

50. Slote M. Moral Sentimentalism. Oxford: Oxford University Press; 2010.

51. Engster D. The Heart of Justice: Care Ethics and Political Theory. Oxford: Oxford University Press; 2007

52. McBryde Johnson H. Unspeakable Conversations. 2003 (Feb 16) New York Times.

53. Vehmas S. Discriminative Assumptions of Utilitarian Bioethics Regarding Individuals with Intellectual Disabilities. Disability \& Society. 1999; 14(1): 37-52.

54. Williams B. Philosophy as a Humanistic Discipline. Princeton, NJ: Princeton University Press; 2006.

55. Cox D, La Caze M and Levine M. Integrity, in Zalta EN. editor, The Stanford Encyclopedia of Philosophy; 2013.

56. Byrne P. Philosophical and Ethical Problems in Mental Handicap. New York: St. Martin's Press; 2000.

57. Vehmas S. Parental Responsibility and the Morality of Selective Abortion. Ethical Theory and Moral Practice. 2002; 5(4): 463-484.

58. Nietzsche F. Beyond Good and Evil: Prelude to a Philosophy of the Future. Johnston I, translator. Arlington, VA: Richer Resources Publications; 2009. 